\title{
Development of Wine Tourism and It's Impact for Local Community in North Bali
}

\author{
Febianti \\ Hospitality Management Program \\ Sekolah Tinggi Pariwisata Bali Internasional \\ Denpasar, Indonesia \\ febiantitantra@gmail.com
}

\author{
Komang Trisna Pratiwi Arcana \\ Tourism Management Program \\ Sekolah Tinggi Pariwisata Bali Internasional \\ Denpasar, Indonesia \\ trisnapratiwi.arcana@gmail.com
}

\begin{abstract}
As the impact of tourism, wine industry in Bali are growing rapidly in recent years. Hotels, restaurants and bars sell numerous amounts of wines. In general perspectives, the image of wine is very close to elegance, relaxation, hedonism, hospitality and tourism. Wines are also have a good pairing with selected foods. Formerly, wines in Bali are very expensive since all wines were imported from major wine producing countries, e.g. France, Australia, USA, and many others. As there were a high demand and opportunities, wine industries in Bali develops since 1990s, however only few sustain due to challenges on legal regulation and economic fluctuation in Indonesia. As Bali still facing the challenges on dividing its tourism to all parts of Bali, not only in southern area, the idea to develop wine tourism could be one of the alternatives. Aims of this study are to identify the contribution of wine industry as the impact of tourism for the local community in North Bali through qualitative research, by interviewing the local community in North Bali and representatives from industries. Both sides are examined in order to conduct a sustainable wine tourism, notably on wine tourism with community involvement in Northern area of Bali. There are plentiful studies had taken previously, but none specifically observing the wines development in Bali and its contribution to the local community.
\end{abstract}

Keywords - wine tourism; tourism impact; north bali; tourism development

\section{INTRODUCTION}

It is noted that international tourist arrivals in many world travel destinations increased by $4 \%$ in the first semester of 2016 (Anonim1, 2016). The increasing traffic levels indicate that tourism has become a lifestyle for the majority of mankind today. Globalization is making this world without limits, increases people's curiosity to new things, especially different experience from daily life (Cooper, 1993).

Bali as one of mainstay tourist destinations in Indonesia noted that the level of tourist arrivals in 2015 exceeded 10.41 million (Anonim2, 2016), accessed on 1st of June 2016). The development of the tourism industry in Bali is still centered on South Bali region like in Badung, Tabanan and Gianyar. This phenomenon would provide opportunities for the region in North Bali areas such as Buleleng regency to take part of the "pie" of tourism.
Buleleng regency is located in the northern island of Bali and has beaches along $144 \mathrm{~km}$ (Anonim3, 2016), accessed on 21st of September 2016). Not surprisingly, one of the leading tourist activities in Buleleng regency definitely utilize water resources such as snorkeling, diving, sea walking, up to coral reef conservation by utilizing the electric known as Biorock System in the area of Pemuteran in Gerogak village. Besides offering the beauty of Marine Tourism, Buleleng regency is also famous for agrotourism through crops such as cloves, coffee, and wine as the manufacture of wine (Anonim4, 2016).

The tropical climate in Indonesia proved to not hinder the growth of the local wine as raw material for the manufacture of various types of wine. Along with the increase in wine consumption in Bali and Balinese wine quality that can compete in the international arena further motivate the wine growers to produce good quality wines. The trend of enjoying wine in Indonesia, especially in Bali due to the high number of Australian tourists who come to visit. Australia is one country that has a strong culture of drinking wine so that the wine tastes developments in Indonesia refers to the tastes of Australia (Fachri, 2014).

As one of the alternative forms of tourism, Wine Tourism began to form to satisfy the desires and travel experience of wine connoisseurs. Wine Tourism is defined as travel activities with visits to vineyards, wineries, wine festival, wine tasting and introducing type of local wine to motivate tourists to come to a destination (Hall iat.al. 2000; Getz, 2000). Jakarta and Bali are the two largest wine consuming destinations in Indonesia, especially the influence of the lifestyle of foreign tourists (Fachri, 2014).

Formerly, wines in Bali are very expensive since all wines were imported from major wine producing countries, e.g. France, Australia, USA, and many others. As there were a high demand and opportunities, wine industries in Bali develops since 1990s, however only few sustain due to challenges on legal regulation and economic fluctuation in Indonesia. The local brand of wine in Bali such as: Hatten Wine in 1992, followed by Sababay in 2010, Cape Discovery in 2012, and Plaga in 2013 (Fachri, 2014).

The limited supply of imported wine grew initiative of entrepreneurs and other tourism stakeholders to develop the 
local wine production with international standards. Starting from the demand for red wine, today the demand for white wine from a local winery it is very promising (www.wineeconomist.com, accessed on 5th of May 2016). This development provides benefits for a number of local farmers in Buleleng regency which is empowered to manage the vineyard as a raw material in the manufacture of Balinese local wine brand. In order to develop sustainable tourism and local community involvement as an important point then travel destinations must highlight the character and uniqueness that is not found in other destinations (Var, et.al. 2006). The development of Wine Tourism in North Bali can be considered as one of the strategies to win market niche and offer different tourist activities on the island which is rich with this cultural heritage.

This study aims to identify the development of wine tourism and its contribution to local communities in Buleleng regency (North Bali).

\section{Wine Tourism}

Wine Tourism are two important components in the wine industry and the tourism industry (Johnson et al, 2000). For destinations that have a foreign market segmentation with wine consuming culture, then the wine is important appeal to a destination and can be the main motivation for tourist travel decisions. As for the wine industry, Wine Tourism is one way to build relationships and provide a different experience through the introduction of types of grapes into wine raw material, as well as direct sales in the wineries of the wine producers. The relationship between the tourism industry and wine are inseparable, since most destinations wine producer has always been a worth destination to visit (Robinson, 1994; Johnson et al, 2000).

Hall (1996) in the Var et.al. (2006) describe Wine Tourism as tourist activities with visits to vineyards, wineries, wine festival, wine tasting and introducing type of local wine to motivate tourists to come to a destination. Added by Getz et al (1999) that the concept of Wine Tourism with the added dimension of experience in travel activity, and revealed that the Wine Tourism is one form of consumer behavior for visiting wine destinations. Furthermore, this development became one of the travel destination marketing strategy and dominant appeal other than cultural attractions and artificial. Getz (2000) also stated that wine destination development assessed on the terms of the dimensions of tourism offerings, namely: attractions, services, infrastructure and tourism establishment or organization.

In 2015, the United Nations of the World Tourism Organization (UNWTO) defines Wine Tourism as an alternative tourism and the unique steps to gain experience of the destination. Creating tourism products and experiences needed to attract tourists with a different motivation and desire to enrich the experience as tourists who come to visit with the reason to study the history and culture of a country.

\section{Tourism Impact}

Tourism is a human activity in a destination with some purpose and consumes the product offered to them with some expectation beyond the activity. This activity takes place in an environment and get in touch with human and natural features (Mason, 2003: 27). Thus the activity will bring some impact to the component that composes of tourism industry. In addition, tourism industry just like any other form of industrial development which give some impacts through the social, physical environment, and the economic in where it takes place and interact with those elements (Cooper et.al. 1993: 94; Mason, 2003: 28).

The impact of tourism activity could be both positive and negative impact. Many researchers had been worked on this context since 1970s and found that negative impacts in tourism were more than the positive impacts (Jafari, 1990; Wall, 1997 in Mason, 2003: 29; Cooper et.al. 1993: 94). A study about tourism impact can be divided in social cultural's aspect; environment's aspect and also economy's aspect. These three dimensions couldn't be separated in accordance with sustainable tourism concept.

Dodd (1995) in Alebaki (2011) describe that a winery visitor is generally of higher educational level and income comparing to average traveller. Also according to the South Australian Tourism Commission (1997) in Alebaki (2011) wine tourist are generally couples with no children, those with higher educational level and those who gained income from professional occupations. By looking up at the typical of the visitors, it will be very potential to be more developed in Bali since it will lead to the sustainable tourism concept.

The regional regulation of Bali Province number 5 in 2012 concerning the controlling of alcoholic beverages commercial circulation stated that alcoholic beverages have a high economic factors, however it could harm the health of the user. Therefore, wine are classified as group "B" with 5\%-20\% ethanol level. Wine circulation in Indonesia also controlled by the douane, or in Indonesian terms "Direktorat Jenderal Bea dan Cukai".

\section{METHOD}

This study attempted to explain the development of Wine Tourism in North Bali, exactly Buleleng regency. The high consumption of wine nowdays provide an opportunity for local wine growers to increase revenues in the tourism industry. Besides discussing the development of Wine Tourism, this paper also try to assess the impact of the growth of this alternative form of tourism for local communities in North Bali. To study this phenomenon, this study used a qualitative approach by conducting a literature study by direct and indirect observation (Sugiyono, 2009) to several wineries and vineyard in Bali. Furthermore, the data collection was continued by interview (Sugiyono, 2009) which support with the interview guidelines on some local wine entrepreneurs in Bali and local communities in the area wineries, Buleleng related to the benefits and impact of the development of Wine Tourism on the island of Bali. The collected data will be presented descriptively. A sample of 2 (two) wineries in Bali are contributed in this study. 


\section{RESULT}

Tourism in Bali are growing fast in recent years. This phenomenon makes a multiplier effect on many aspect in society, not only in economic side, but also in socio-cultural side. In economic side, tourism offer plenty jobs to community and brings impact on infrastructure development. Alcoholic beverages, such as "arak", had already well known and well used in Bali for a very long time, since it is used for traditional ceremonies. However, wine was originally imported from many countries outside Indonesia, such as France, Australia, and many more. In Indonesia, wine are classfied as in group "B", with 5\%-20\% ethanol level, while group "A" includes beers and group " $\mathrm{C}$ " includes liquors. According to regional regulation, consumers can only find and buy wines in a licensed retailers.

Wine is really identical with relaxation and food pairing, therefore wine is very close to the tourism industry. With its connection to the "terroir" concept, which includes environment, material, and human resources, every wines are unique and could not be the same from region to region. Material resources are includes the grape itself, and all material that is used to make a wine. Environment resources includes local weather and climates. Human resources includes all people who contributing in wine making. This means wine producing are very depending on local sorrounding. Based on researchers interview with Jeremy, a research and development specialist in Hatten Wines, Bali, there are originally 2 types of grapes. There are wine grape, which is the basic ingredients of wine, and table grape, which is a typical fruit that is served on the dining table.

Based on reserchers interview to both of the local wineries in Bali, Hatten Wines and Sababay Winery, types of grapes that they used as the ingredients called Alphonse Lavallee. Alphonse Lavallee was originated from France and had already found in Bali since long time ago, however there is no data showed who and when this grapes planted for the very first time in Bali. It probably came and brought as the impact of colonialism or misionaries, however there are no strong evidence that may be found. The most well spread vineyard are found in North Bali area, Buleleng Regency. In this area, the Alphonse Lavallee are planted and viticultured by the local farmers.

Along with the development of agrotourism in Bali, a vineyard visit can also be the alternative of tourism in Bali. Supported by the climate and soil condition, North Bali is the perfect region for the vineyard visit. Here are some data collected from 2 (two) local wineries in Bali :

Hatten wines uses local grapes for its production. As the pioneer of wine making and vineyard visits in Bali, Hatten Wines gained reputable international recognition. Hatten wine had their own vineyard, and opens its vineyards during working days from Monday to Saturday for public visits in Buleleng. It also had a cellardoor as their lifestyle boutique which targeting daily consumers in Sanur area. Founded by Ida Bagus Rai Budarsa in 1994, Hatten Wines have a range varieties of product made from the local black grapes Alphonse Lavallee and white grapes varieties of Belgia and Proboliingo Biru. In their vineyard, all farmers are locals, while at the same time the company also provide a study visit for students. It also conducts an internship training for local university students. In the cellar door, Hatten Wines also offers wine class to pursue its educational mission. Not only providing jobs for local communities, Hatten Wines also contributing in North Bali Alliance on supporting local orphanage. Products of Hatten Wines includes Aga White (dry white wine), Aga Red (medium bodied red wine), Alexandria (very fruity and perfumed grape flavour-white wine), Hatten Wines Rosé, Tunjung (brut sparkling), Jepun Sparkling Rosé, Pino de Bali (fortified wine)

Sababay Winery is an Indonesian winery which produced its wine product in Teluk Saba, Bali. Sababay winery in collaboration with Asteroid R\&D vineyard and local farmer integrating farmers concept which resulting in sustainable harvest. Founded in 2010, Sababay Winery contributing on farmers economic development, notably through making the system fairer for everyone else. "Early 2000 was a series of though years for most grapes in Bali, especially in Buleleng because of crop disease, poor marketing and failed harvest forced many farmers to borrow money at high interest rate" stated by local farmers. Asteroid, a subsidiaries of Sababay, offers the Farmers Partnership Agreement which implement advance viticulture techniques. There are 175 farmers work with Asteroid and gained price 10 (ten) times higher with a good quality. In this case, Sababay is not only jobs to the local community, but also viticulture education and economic development. Asteroid also make a commitment to hire wifes of the farmers to grap pick the harvest. In return, farmers should follow a specified viticulture routine and sells their product uniquely to Asteroid. Products os Sababay Winery are Pink Blossom (rose), Black Velvet (red wine), Reserve Red (dry red wine), and White Velvet. Through a visit to Sababay Winery, visitors could also do some wine tasting.

\section{CONCLUSION}

Wine tourism is very potential to be developed in Bali, especially in Northern Bali. Based on the finding and discussion, it may take several pros and cons however it also may increase the economy. The bad impact ot wine, could be anticipated by forming the more detailed regulation with a strong law enforcement. Wine tourism itself could not only enhance Bali's tourism by giving more diversified choices of tourism attraction in Bali, but also could give a direct impact on economic development to local farmers.

Along with the development of tourism in Bali, and tourist intention to Balinese wine, possibly that wine tourism could be developed in Nothern Bali. Tourism sectors, which is already crowded in Southern Bali, could be spread into Northern area by developing a vineyard visit, so it will enhance the economic level of local farmers. Several wine industries in Bali are noted as having a contribution for the local community. Not only offers more job opportunities, this industries also gives education for their local society. Not supporting local orphanage, but spread wine knowledge and viticulture education. These mutualism relation will leads to sustainable tourism which in line with the contribution to the local community. 
Since wine tourist are generally couples with no children, those with higher educational level and those who gained income from professional occupations, Bali could also elevate its "brand" into the more elegant tourist destination. It won't be mass and destroying. The vineyard visit concept which followed by wine tasting and educational explaination will give a unique experience to the visitors. In the other hand, the concept of food pairing also may elevate the local culinary. Along with its uniqueness of "terroir", every wine in the world will have different taste and also different pair of food.

This study was only described on phenomenon of wine tourism in Bali with a brief explanation of its contribution to the local farmers in North Bali. As a reference, researchers wish that future study could identify in more detail of wine tourism in Indonesia.

\section{REFERENCES}

Alebaki, Maria, Iakovidou, \& Olga. (2011). "Market Segmentation of Wine Tourism: A Comparison of Approaches". Tourism: An International Multidisciplinary Journal of Tourism. 6 (1),123-140.

Anonim. (2015). "UNWTO Wine Tourism Prototype". (www.UNWTO.org, accessed on 20th of September 2016).

Anonim". (2016). "International Tourist Arrivals up 4\% in The First Half of 2016". (http://mkt.unwto.org/barometer/september-2016volume-14, accessed on 20th of September 2016).

Anonim ${ }^{2}$. (2016). "Statistik Pariwisata Bali 2015". (http://www.disparda.baliprov.go.id/id/Statistik3, accessed on 1st of June 2016).

Anonim ${ }^{3}$. (2016). "Dinas Kebudayaan dan Pariwisata Pemerintah Kabupaten Buleleng". (www.disbudpar.bulelengkab.go.id, accessed on 21st of September 2016).

Anonim $^{4}$, (2016). (http://buleleng.dewatanews.com, accessed on $21^{\text {st }}$ of September 2016)

Anonim. (2016). "Sababay Wines of Bali: New Latitudes, New Flavors, New Frontiers". (https://www.wineeconomist.com, accessed on 5th of May 2016).

Anonim. (2016). "Hatten Wines: Proudly Balinese". (http://www.hattenwines.com/ , accessed on $5^{\text {th }}$ May 2016)

Bruwer, Johan and Alant, Karin. (2009). "The hedonic nature of wine tourism consumption: an experiential view". International Journal of Wine Business Research. 21 (3).Bingley: Emerald Group Publishing.
Cooper, Chris. et.al. (1993). "Tourism Principles and Practice". England: Longman.

Fachri, Andi. (2014). "Sekilas Tentang Industri Wine di Indonesia". (https://www.linkedin.com, accessed on $25^{\text {th }}$ of September 2016).

Getz, Donald et.al. (1999). “Critical Success Factors for Wine Tourism". Internasional Journal of Marketing. 11 (3), pp. 20-43.

Getz, D. (2000). "Explore Wine Tourism: Management, Development and Destinations." Cognizant: New York.

Handoyo, Y. (2007). "Rahasia Wine". Jakarta: Gramedia Pustaka Utama.

Hall, C.M., Longo, A.M., Mitchell, R. and Johnson, G. (2000). "Wine tourism in New Zealand" in. Hall C.M, Sharples L., Cambourne B. and Macionis N. (Eds). "Wine Tourism around the World: Development, Management and Markets". Oxford: Elsevier Science, pp. 150-176.

Jelita, F. J. (2013). "Sensasi Anggur Lokal". (http://www.hattenwines.com/press-center/ , accessed on $5^{\text {th }}$ September 2016).

Johnson, Gary; Brock Cambourne; Ritchard Mitchell; et al. (2000). "Wine Tourism: An Introduction". First Edition. in. Hall C.M, Sharples L., Cambourne B. and Macionis N. (Eds). "Wine Tourism around the World: Development, Management and Markets". Oxford: Elsevier Science.

Kartajaya, Hermawan and Nirwandar, Sapta. (2013). "Tourism Marketing 3.0: Turning Tourist to Advocate". Jakarta: Gramedia Pustaka Utama.

Mason, Peter. (2003). "Tourism Impacts, Planning and Management". Oxford: Butterworth - Heinemann.

Matthews, Georgina and Milroy, Ella. (2004). "Wines of the world : Your essential handbook”. New York: DK Publishing Inc.

Sugiyono. (2009). "Metode Penelitian Pendidikan (Pendekatan Kuantitatif, Kualitatif, dan R\&D”. Cetakan Ke-7. Bandung: Alfabeta.

Utama, I Gusti Bagus Rai. (2016). “Metodologi Penelitian Pariwisata \& Hospitalitas (Dilengkapi Studi Kasus Penelitian)". Denpasar: Pustaka Larasan.

Var, Turgut, Melike D. Kaplan, and Oznur Yurt. (2006). "Challenges and Opportunities of Developing Wine Tourism in Small Community in Turkey". E-Review of Tourism Research (eRTR). 4 (1).

Wargenau, Astrid and Che, Deborah. (2006). "Wine tourism development and marketing strategies in Southwest Michigan". International Journal of Wine Marketing. 18 (1), $45-60$. 